\title{
KESTABILAN TITIK TETAP MODEL PENULARAN PENYAKIT TIDAK FATAL
}

\author{
AKHIRUDDIN \\ Program Studi Matematika, \\ Fakultas Matematika dan Ilmu Pengetahuan Alam, Universitas Andalas, \\ Kampus UNAND Limau Manis Padang, Indonesia, \\ akhir-ainan@yahoo.co.id
}

\begin{abstract}
Abstrak. Dalam tulisan ini akan dikaji kestabilan titik tetap suatu model penularan penyakit tidak fatal, dimana model tersebut merupakan model klasik (model SIR) yang sudah lama ditemukan, dengan asumsi laju kelahiran sama dengan laju kematian, diperoleh bahwa hanya satu titik tetap yang stabil asimtotik.
\end{abstract}

Kata Kunci: Kestabilan titik tetap, model klasik (model SIR), stabil asimtotik

\section{Pendahuluan}

Penyebaran suatu penyakit merupakan salah satu ancaman terhadap manusia, terutama penyakit menular yang dibawa oleh berbagai macam mikroba seperti bakteri, jamur, parasit dan virus. Terdapat dua tipe akibat yang ditimbulkan oleh penyakit menular. Pertama penyakit yang menyebabkan kematian (fatal), misal penyakit AIDS, TBC, flu burung. Kedua penyakit yang tidak menyebabkan kematian (tidak fatal), misal penyakit campak, demam berdarah.

Penyakit tidak fatal, dalam hal ini penyakit campak merupakan penyakit yang sangat berbahaya, penyakit tersebut disebabkan oleh virus yang dapat menyebar melalui kontak langsung dengan penderita, udara dan batuk. Tubuh mempunyai kemampuan untuk mengatasi sampai batas tertentu. Dalam hal ini, dikatakan bahwa sistem pertahanan tubuh (sistem imun) orang tersebut cukup baik untuk mengatasi dan mengalahkan kuman-kuman penyakit tersebut. Tetapi bila kuman penyakit tesebut ganas, sistem pertahanan tubuh yang lemah tidak mampu mencegah kuman atau virus itu berkembangbiak, sehingga dapat mengakibatkan penyakit berat yang membawa kepada kecacatan pada sipenderita (tidak fatal).

Perkembangan ilmu pengetahuan di bidang matematika juga turut mememberikan peranan penting dalam mencegah meluasnya penyebaran penyakit tidak fatal (Castelli dan Romanelli, 2009). Peranan tersebut berupa model matematika yang mempelajari penyebaran penyakit. Matematika memberikan salah satu solusi penyelesaian penyebaran penyakit tidak fatal. Penyebaran penyakit ini akan dimodelkan ke dalam bentuk matematis menggunakan tipe model SIR. Model SIR (Susceptibles, Invectives, Recovered) ini pada awalnya dikembangkan untuk mengetahui laju penyebaran dan kepunahan suatu wabah penyakit dalam populasi tertutup dan bersifat epidemik. 
Model SIR dikemukakan pertama kali oleh Kermack dan McKendrick pada tahun 1927. Disini akan dibahas mengenai pembentukan model SIR dengan menganalisis kestabilan titik tetap model penularan penyakit tidak fatal dan berdasarkan asumsi-asumsi yang dibuat. Setelah model terbentuk, kemudian dicari solusi analitis dan kestabilan titik tetapnya.

\section{Teori Matriks}

Definisi 2.1. [3] Jika A adalah sebuah matriks $n \times n$, maka suatu vektor tak nol $\mathbf{x} \in \mathbb{R}^{n}$ disebut vektor eigen(eigenvector) dari A jika Ax adalah sebuah kelipatan skalar dari $\mathbf{x}$, yakni

$$
A \mathbf{x}=\lambda \mathbf{x},
$$

untuk suatu skalar $\lambda$. Skalar $\lambda$ desebut nilai eigen(eigenvalue) dari $A$ dan $\mathbf{x}$ disebut sebagai vektor eigen dari A yang terkait dengan $\lambda$.

Nilai eigen $\lambda$ merupakan akar dari polonomial berikut

$$
p_{A}(\lambda)=\operatorname{det}(\lambda I-A) .
$$

Dalam hal ini, $p_{A}(\lambda)$ dikatakan polinomial karakteristik dari matriks $A$.

Teorema 2.2. [4] (Teorema Cayley - Hamilton) Misalkan $p_{A}(\lambda)$ polinomial karakteristik dari matriks $A \in \mathbb{R}^{n x n}$, maka

$$
p_{A}(A)=0 .
$$

Definisi 2.3. [2] Dua matriks $A, B \in \mathbb{R}^{2 \times 2}$ dikatakan similar, ditulis $A \approx B$, jika dan hanya jika terdapat matriks $M$ non singular $n \times n$ sehingga

$$
M^{-1} A M=B .
$$

Teorema 2.4. [1] Jika A matriks berukuran $n \times n, I$ matriks identitas berukuran $n \times n$ dan $\lambda$ suatu bilangan real, maka pernyataan-pernyataan berikut ekuivalen :

(1) $\lambda$ adalah suatu nilai eigen dari $A$,

(2) Sistem persamaan $\left(A-\lambda I_{n \times n}\right) \mathbf{x}=\overline{0}$ mempunyai penyelesaian tak trivial.

(3) Ada suatu vektor tak nol $\mathbf{x}$ pada $\mathbb{R}^{n}$ sedemikian sehingga $A \mathbf{x}=\lambda \mathbf{x}$.

(4) $\lambda$ merupakan suatu penyelesaian dari persamaan karakteristik $\operatorname{det}\left(A-\lambda I_{n \times n}\right)=0$.

\section{Kestabilan Sistem Persamaan Diferensial Non Linier Orde Satu}

Diberikan sistem dinamis

$$
\dot{\mathbf{x}}=\mathbf{f}(\mathbf{x}), \mathbf{x} \in \mathbb{R}^{n},
$$

dengan $\mathbf{f}(\mathbf{x})$ adalah fungsi non linier yang dapat diturunkan. Untuk sistem non linier, biasanya solusi eksak sulit untuk ditentukan.

Dalam [5] dinyatakan bahwa perilaku solusi dari sistem non linier (3.1) dapat diaproksimasi melalui sistem pelinierannya. Salah satu metode yang digunakan adalah metode deret Taylor. 
Berikut ini akan dipaparkan bagaimana menentukan sistem pelinieran dari suatu sistem persamaan diferensial non linier dengan menggunakan deret Taylor.

Deret Taylor untuk fungsi dengan dua variabel bebas $f(x, y)$ disekitar titik $\left(c_{1}, c_{2}\right)$ adalah

$$
\begin{aligned}
f(x, y)= & f\left(c_{1}, c_{2}\right)+\left(\frac{\partial f}{\partial x}\left(c_{1}, c_{2}\right)\left(x-c_{1}\right)+\frac{\partial f}{\partial y}\left(c_{1}, c_{2}\right)\left(y-c_{2}\right)\right) \\
& +\left(\frac{\partial^{2} f}{\partial x^{2}}\left(c_{1}, c_{2}\right) \frac{\left(x-c_{1}\right)^{2}}{2 !}+\frac{\partial^{2} f}{\partial y^{2}}\left(c_{1}, c_{2}\right) \frac{\left(y-c_{2}\right)^{2}}{2 !}\right) \\
& +\left(\frac{\partial^{2} f}{\partial x \partial y}\left(c_{1}, c_{2}\right)\left(x-c_{1}\right)\left(y-c_{2}\right)\right)+\cdots .
\end{aligned}
$$

Diberikan sistem dinamis di $\mathbb{R}^{2}$ sebagai berikut:

$$
\begin{aligned}
& \dot{x}_{1}=f_{1}\left(x_{1}, x_{2}\right) \\
& \dot{x}_{2}=f_{2}\left(x_{1}, x_{2}\right) .
\end{aligned}
$$

Misalkan komponen fungsi $f_{i}\left(x_{1}, x_{2}\right), i=1,2$, punya turunan yang kontinu di sekitar titik $\left(c_{1}, c_{2}\right)$. Deret Taylor dari $f_{i}\left(x_{1}, x_{2}\right), i=1,2$ adalah

$$
\begin{aligned}
f_{i}\left(x_{1}, x_{2}\right)= & f_{i}\left(c_{1}, c_{2}\right)+\left(x_{1}-c_{1}\right) \frac{\partial f_{i}}{\partial x_{1}}\left(c_{1}, c_{2}\right) \\
& +\left(x_{2}-c_{2}\right) \frac{\partial f_{i}}{\partial x_{2}}\left(c_{1}, c_{2}\right)+\text { suku orde tinggi. }
\end{aligned}
$$

Karena $\left(c_{1}, c_{2}\right)$ adalah titik tetap dari (3.3) maka $f_{i}\left(c_{1}, c_{2}\right)=0, i=1,2$. Misalkan $y_{i}=x_{i}-c_{i}, i=1,2$, maka (3.3) dapat ditulis menjadi

$$
\begin{aligned}
& \dot{y_{1}}=y_{1} \frac{\partial f_{1}}{\partial x_{1}}\left(c_{1}, c_{2}\right)+y_{2} \frac{\partial f_{1}}{x_{2}}\left(c_{1}, c_{2}\right)+\text { suku orde tinggi } \\
& \dot{y_{2}}=y_{1} \frac{\partial f_{2}}{\partial x_{1}}\left(c_{1}, c_{2}\right)+y_{2} \frac{\partial f_{2}}{x_{2}}\left(c_{1}, c_{2}\right)+\text { suku orde tinggi. }
\end{aligned}
$$

Secara ringkas, ditulis

$$
\dot{\mathbf{y}}=J \mathbf{y}
$$

dimana

$$
J=\left[\begin{array}{ll}
\frac{\partial f_{1}}{\partial x_{1}} & \frac{\partial f_{1}}{\partial x_{2}} \\
\frac{\partial f_{2}}{\partial x_{1}} & \frac{\partial f_{2}}{\partial x_{2}}
\end{array}\right]_{\left(x_{1}, x_{2}\right)=\left(c_{1}, c_{2}\right)}
$$

Matriks $J$ disebut sebagai matriks Jacobian. Sistem (3.6) disebut sebagai sistem pelinearan dari sistem non linier (3.3) [8].

Teorema berikut merupakan syarat cukup agar sisem persamaan diferensial non linier (3.1) stabil asimtotik.

Teorema 3.1. [2] Misalkan $\overline{\boldsymbol{c}}$ adalah titik tetap dari sistem non linier

$$
\dot{\mathbf{x}}=\mathbf{f}(\mathbf{x}) \text {. }
$$

Jika bagian riil dari semua nilai eigen matriks Jacobian $J$ di $\overline{\boldsymbol{c}}$ dari sistem non linier tersebut adalah negatif, maka titik tetap $\overline{\boldsymbol{c}}$ adalah stabil asimtotik. 


\section{Konstruksi Model}

Dalam suatu populasi yang berukuran tetap pada suatu periode wabah, misalkan terjadi penyebaran suatu penyakit tidak fatal (tidak menimbulkan kematian). Selanjutnya, misalkan $S(t)$ menyatakan proporsi anggota populasi yang rentan terkena penyakit tersebut pada waktu $t, I(t)$ menyatakan proporsi anggota populasi yang sudah terjangkit pada waktu $t$ dan $R(t)$ menyatakan proporsi anggota populasi yang sudah sembuh dari penyakit tersebut pada waktu $t$. Hubungan antara proporsi populasi $S(t), I(t), R(t)$ memenuhi persamaan

$$
S(t)+I(t)+R(t)=1
$$

Selanjutnya, asumsikan :

(1) Populasi tertutup (tidak ada proses migrasi).

(2) Penyakit dapat disembuhkan dan penularan penyakit langsung (tidak ada masa inkubasi), melalui kontak langsung antara individu rentan dengan penderita.

(3) Setiap individu yang belum terserang penyakit masuk ke populasi rentan terkena penyakit $(\mathrm{S})$.

(4) Individu yang sembuh mempunyai kekebalan dalam jangka waktu tertentu.

(5) Laju kelahiran dan laju kematian adalah konstan berturut-turut ditulis dengan $\nu$ dan $\mu$ dimana $\nu=\mu$.

(6) Masa terjangkit yang cukup lama.

Penularan penyakit diasumsikan terjadi karena kontak yang tetap dari subpopulasi $S$ dan $I$ dalam populasi tersebut. Nilai dari $\dot{S}$ akan bertambah dengan munculnya kelahiran baru $(\nu)$ dan akan berkurang dengan adanya kematian $(\mu)$. Selain itu, misalkan laju penularan penyakit adalah $\beta$, maka perubahan jumlah subpopulasi yang rentan pada waktu $t$ memenuhi hubungan :

$$
\dot{S}=\nu-\beta I S-\mu S
$$

dengan $\nu, \beta, \mu$ adalah konstanta positif. Jika $\gamma>0$ adalah laju kesembuhan, maka

$$
\dot{I}=\beta I S-\gamma I-\mu I
$$

dengan $\mu I$ adalah jumlah kematian pada subpopulasi $I$, dan laju perubahan subpopulasi recovered menjadi

$$
\dot{R}=\gamma I-\mu R
$$

dengan $\mu R$ adalah jumlah kematian dari subpopulasi $R$. Proses pembentukan persamaan (4.2), (4.3) dan (4.4) di perlihatkan dalam Gambar 4.1 dibawah ini.

Dari tiga buah persamaan di atas, diperoleh sistem persamaan diferensial non linier berikut [5]:

$$
\begin{aligned}
\dot{S} & =\nu-\beta I S-\mu S \\
\dot{I} & =\beta I S-\gamma I-\mu I \\
\dot{R} & =\gamma I-\mu R
\end{aligned}
$$




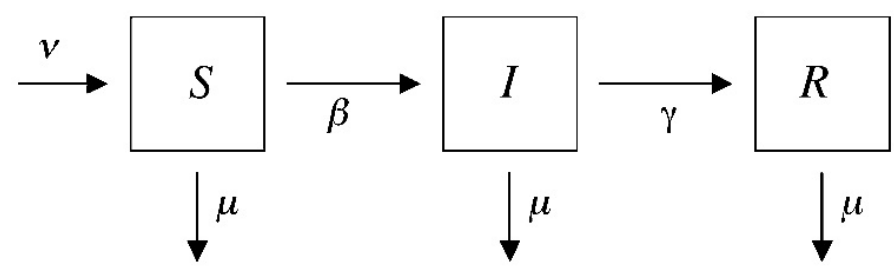

Gambar 4.1. Diagram Model SIR

\section{Kestabilan Titik Tetap Model Penularan Penyakit Tidak Fatal}

Dari sistem (4.5), dapat dilihat bahwa persamaan pertama dan kedua tidak dipengaruhi oleh persamaan ketiga, oleh karena itu persamaan ketiga dapat diabaikan. Sehingga, cukup diperhatikan sistem yang terdiri atas dua persamaan diferensial non linier berikut :

$$
\begin{aligned}
& \dot{S}=\nu-\beta I S-\mu S \\
& \dot{I}=\beta I S-\gamma I-\mu I
\end{aligned}
$$

Terlebih dahulu, akan ditentukan titik tetap sistem (5.1). Sesuai dengan definisi titik tetap, maka diperoleh :

$$
\begin{aligned}
& \dot{S}=\nu-\beta I S-\mu S=0 \\
& \dot{I}=\beta I S-\gamma I-\mu I=0
\end{aligned}
$$

Dari (5.3) diperoleh $I=0$ atau $S=\frac{\gamma+\mu}{\beta}$. Jika $I=0$, maka dari (5.2) diperoleh

$$
S=\frac{\nu}{\mu}=1,
$$

sehingga $(S, I)=(1,0)$ adalah suatu titik tetap.

Selanjutnya, jika $S=\frac{\gamma+\mu}{\beta}$ maka dari (5.2) diperoleh

$$
I=\frac{\nu}{\gamma+\mu}-\frac{\mu}{\beta}
$$

sehingga $(S, I)=\left(\frac{\gamma+\mu}{\beta}, \frac{\nu}{\gamma+\mu}-\frac{\mu}{\beta}\right)$ merupakan titik tetap kedua dari sistem (5.1).

Dalam kehidupan nyata, jumlah populasi manusia tidak mungkin negatif, oleh karena itu nilai titik tetap harus bernilai positif. $\frac{\gamma+\mu}{\beta}$ sudah pasti positif, sehingga yang perlu diberi syarat adalah $\frac{\nu}{\gamma+\mu}-\frac{\mu}{\beta}>0$, atau

$$
\beta-\gamma-\mu>0 \text {. }
$$

Selanjutnya, akan ditentukan pelinieran dari (5.1) di kedua titik tetap tersebut. Misalkan :

$$
\begin{gathered}
f(S, I)=\nu-\beta I S-\mu S \\
g(S, I)=\beta I S-\gamma I-\mu I,
\end{gathered}
$$

Jacobian dari sistem (5.1) adalah 


$$
J=\left[\begin{array}{ll}
\frac{\partial f(S, I)}{\partial S} & \frac{\partial f(S, I)}{\partial I} \\
\frac{\partial g(S, I)}{\partial S} & \frac{\partial g(S, I)}{\partial I}
\end{array}\right]=\left[\begin{array}{cc}
-\beta I-\mu & -\beta S \\
\beta I & \beta S-\gamma-\mu
\end{array}\right]
$$

Di titik tetap $(S, I)=(1,0)$, matriks Jacobian $J$ adalah :

$$
J(1,0)=\left[\begin{array}{cc}
-\mu & -\beta \\
0 & \beta-\gamma-\mu
\end{array}\right] .
$$

Nilai eigen dari matriks $J(1,0)$ adalah $\lambda_{1}=-\mu$ dan $\lambda_{2}=\beta-\gamma-\mu$. Berdasarkan Teorema 3.1, titik tetap $(1,0)$ akan stabil asimtotik jika $\beta<\gamma+\mu$. Hal ini bertentangan dengan syarat (5.4) untuk titik tetap yang kedua. Jadi tidak mungkin titik tetap $(1,0)$ stabil asimtotik.

Pada titik tetap $(S, I)=\left(\frac{\gamma+\mu}{\beta}, \frac{\nu}{\gamma+\mu}-\frac{\mu}{\beta}\right)$ matriks Jacobian $J$ adalah :

$$
J\left(\frac{\gamma+\mu}{\beta}, \frac{\nu}{\gamma+\mu}-\frac{\mu}{\beta}\right)=\left[\begin{array}{cc}
-\frac{\beta \nu}{\gamma+\mu} & -(\gamma+\mu) \\
\frac{\beta \nu}{\gamma+\mu}-\mu & 0
\end{array}\right]
$$

Nilai eigen dari matriks $J\left(\frac{\gamma+\mu}{\beta}, \frac{\nu}{\gamma+\mu}-\frac{\mu}{\beta}\right)$ ditentukan sebagai berikut :

$$
\left|\lambda I-J\left(\frac{\gamma+\mu}{\beta}, \frac{\nu}{\gamma+\mu}-\frac{\mu}{\beta}\right)\right|=\lambda^{2}+\frac{\beta \nu}{\gamma+\mu} \lambda-(\gamma+\mu) \mu+\beta \nu=0 .
$$

Akar dari polinomial (5.8) adalah

$$
\lambda_{1,2}=\frac{-\frac{\beta \nu}{\gamma+\mu}}{2} \pm \frac{\sqrt{\left(\frac{\beta \nu}{\gamma+\mu}\right)^{2}-4[\beta \nu-(\gamma+\mu) \mu]}}{2} .
$$

Berdasarkan Teorema 3.1, titik tetap $\left(\frac{\gamma+\mu}{\beta}, \frac{\nu}{\gamma+\mu}-\frac{\mu}{\beta}\right)$ akan stabil asimtotik jika bagian riil dari nilai eigen adalah negatif. Oleh karena itu, misalkan

$$
-\frac{\beta \nu}{\gamma+\mu}+\sqrt{\left(\frac{\beta \nu}{\gamma+\mu}\right)^{2}-4[\beta \nu-(\gamma+\mu) \mu]}<0 .
$$

Persamaan (5.10) ekivalen dengan

$$
\begin{aligned}
\sqrt{\left(\frac{\beta \nu}{\gamma+\mu}\right)^{2}-4[\beta \nu-(\gamma+\mu) \mu]} & <\frac{\beta \nu}{\gamma+\mu} \\
\beta-\gamma-\mu & >0,
\end{aligned}
$$

yang memenuhi syarat (5.4). Ini menunjukkan bahwa titik tetap $(S, I)=$ $\left(\frac{\gamma+\mu}{\beta}, \frac{\nu}{\gamma+\mu}-\frac{\mu}{\beta}\right)$ adalah stabil asimtotik.

Sebagai suatu ilustrasi, misalkan $\nu=0,07, \mu=0,07, \beta=1,66, \gamma=0,44$, diperoleh sistem persamaan diferensial non linier berikut :

$$
\begin{aligned}
\dot{S} & =0,07-1,66 I S-0,07 S \\
\dot{I} & =1,66 I S-0,51 I \\
\dot{R} & =0,44 I-0,07 R .
\end{aligned}
$$


64 Akhiruddin

Perhatikan sistem

$$
\begin{aligned}
\dot{S} & =0,07-1,66 I S-0,07 S \\
\dot{I} & =1,66 I S-0,51 I
\end{aligned}
$$

Terlebih dahulu, akan ditentukan titik tetap sistem (5.11). Sesuai dengan definisi titik tetap, maka diperoleh :

$$
\begin{aligned}
\dot{S}=0,07-1,66 I S-0,07 S & =0 \\
\dot{I}=1,66 I S-0,51 I & =0 .
\end{aligned}
$$

Dari (5.15) diperoleh $I=0$ atau $S=0$,31. Jika $I=0$, maka dari (5.14) diperoleh

$$
S=\frac{0,07}{0,07}=1
$$

sehingga $(S, I)=(1,0)$ adalah suatu titik tetap. Selanjutnya, jika $S=0,31$ maka dari (5.14) diperoleh

$$
I=0,098
$$

sehingga $(S, I)=(0,31,0,098)$ merupakan titik tetap kedua dari sistem (5.11).

Selanjutnya, akan ditentukan pelinieran dari (5.11) di kedua titik tetap tersebut. Misalkan :

$$
\begin{gathered}
f(S, I)=0,07-1,66 I S-0,07 S \\
g(S, I)=1,66 I S-0,51 I,
\end{gathered}
$$

jacobian dari sistem (5.11) adalah

$$
J=\left[\begin{array}{ll}
\frac{\partial f(S, I)}{\partial S} & \frac{\partial f(S, I)}{\partial I} \\
\frac{\partial g(S, I)}{\partial S} & \frac{\partial g(S, I)}{\partial I}
\end{array}\right]=\left[\begin{array}{cc}
-1,66 I-0,07 & -1,66 S \\
1,66 I & 1,66 S-0,51
\end{array}\right]
$$

Di titik tetap $(S, I)=(1,0)$, matrix jacobian $J$ adalah :

$$
J(1,0)=\left[\begin{array}{cc}
-0,07 & -1,66 \\
0 & 1,15
\end{array}\right] .
$$

Nilai eigen dari matriks $J(1,0)$ adalah $\lambda_{1}=-0,07, \lambda_{2}=1,15$.

Berdasarkan Teorema 3.1, titik tetap $(1,0)$ adalah tidak stabil asimtotik.

Selanjutnya, di titik tetap $(S, I)=(0,31,0,098)$, matrix jacobian $J$ adalah :

$$
J(0,31,0,098)=\left[\begin{array}{cc}
-0,233 & -0,51 \\
0,163 & 0
\end{array}\right] .
$$

Nilai eigen dari matriks $J(0,31,0,098)$ ditentukan sebagai berikut :

$$
|\lambda I-J(0,31,0,098)|=\lambda^{2}+0,233 \lambda+0,083=0 .=0 .
$$

Akar dari polinomial (5.20) adalah

$$
\lambda_{1,2}=-0,1165 \pm \frac{\sqrt{-0,278}}{2} .
$$


Dari (5.21) diperoleh bahwa

$$
\operatorname{Re}\left(\lambda_{1}\right)=\operatorname{Re}\left(\lambda_{2}\right)=-0,1165<0,
$$

Berdasarkan Teorema (3.1), titik tetap $(S, I)=(0,31,0,098)$ adalah stabil asimtotik.

\section{Kesimpulan}

Berdasarkan hasil yang diperoleh dari pembahasan sebelumnya, terdapat sistem persamaan diferensial non linier berikut:

$$
\begin{aligned}
\dot{S} & =\nu-\beta I S-\mu S \\
\dot{I} & =\beta I S-\gamma I-\mu I \\
\dot{R} & =\gamma I-\mu R
\end{aligned}
$$

dengan populasi $S(t), I(t), R(t)$ memenuhi persamaan $S(t)+I(t)+R(t)=1$.

Setelah menganalisis sistem (6.1) diperoleh dua titik tetap, yaitu $(1,0)$ dan $\left(\frac{\gamma+\mu}{\beta}, \frac{\nu}{\gamma+\mu}-\frac{\mu}{\beta}\right)$ dengan syarat $\beta>\gamma+\mu$. Titik tetap $(1,0)$ adalah tidak stabil asimtotik, sedangkan titik tetap $\left(\frac{\gamma+\mu}{\beta}, \frac{\nu}{\gamma+\mu}-\frac{\mu}{\beta}\right)$ adalah stabil asimtotik.

\section{Ucapan Terima kasih}

Penulis mengucapkan terima kasih kepada Bapak Dr. Muhafzan, Bapak Efendi, M. Si, Ibu Nova Noliza Bakar, M. Si, Ibu Dr. Maiyasti dan Bapak Dr. Ahmad Iqbal Baqi yang telah memberikan masukan dan saran sehingga paper ini dapat diselesaikan dengan baik.

\section{Daftar Pustaka}

[1] Anton, H. 2000, Dasar-Dasar Aljabar Linear, edisi ketujuh, (diterjemahkan oleh H. Suminto,), Interaksara, Batam.

[2] Arrowsmith, D. K and C. M. Place. 1990, Ordinary Differential Equations. Chapter and Hall, Singapore.

[3] Boyce, W. E and R. C DiPrima. 1992. Elementary Differential Equations and Boundary Value Problems. 5th Edition. John Wiley and Son, Inc, Canada.

[4] Horn, R. A and R. J. Charles. 1999, Matrix Analysis. Cambridge University Press, USA.

[5] Murray, J. D. 1993, Mathematical Biology, 2nd edition, Springer-Verlag, Berlin. 